Sains Malaysiana 49(6)(2020): 1209-1222

http://dx.doi.org/10.17576/jsm-2020-4906-01

\title{
Phenomenon of Macrophyte Differentiation in a Small Lake
}

(Fenomenon Pembezaan Makrofit di Suatu Tasik Kecil)

\author{
SENDER JOANNA*, DANUTA URBAN \& RÓŻAŃSKA-BOCZUla MONIKA
}

\begin{abstract}
The main objective of the research was to determine the causes of qualitative and quantitative variability of macrophytes within the lake. The study involved the analysis on factors warning their diversity, and also to understand if these factors were inside or outside the lake. In addition, attempts were made to indicate which group of macrophytes showing the strongest response to these factors. The determination of such factors will permit taking protective measures regarding the lake. Lake Gtębokie Uścimowskie is located in the western part of the Łęczna-Włodawa Lake District (Poland). It is an eutrophic water body with a surface area of 20.5 ha and maximum depth $7.1 \mathrm{~m}$. Lake Gtębokie Uścimowskie is a small and shallow lake constituting a diverse habitat for macrophytes. The littoral slope, buffer zone slope, and buffer zone land use had the greatest impact on the macrophyte diversity of the lake. An increase in the value of these variables affected features such as helophyte biomass, helophyte range, and depth of macrophyte occurrence to the greatest degree. Wind direction, which influenced the number of nympheid species, was also highly correlated. The Secchi disc visibility variable had the strongest influence on submerged macrophytes. As a rule, in the studied lake, if the rushes zone was developed, the development of submerged macrophytes was limited. Poorly developed rushes were accompanied by greater variability among submerged macrophytes.
\end{abstract}

Keywords: Abiotic factors; differentiation; macrophytes; shallow lake; species morphology

\section{ABSTRAK}

Objektif utama penyelidikan ini adalah untuk menentukan punca variasi kualitatif dan kuantitatif makrofit di dalam tasik. Kajian ini melibatkan analisis mengenai faktor-faktor yang memperingatkan kepelbagaian mereka, dan juga untuk memahami adakah faktor-faktor ini berada di dalam atau di luar tasik. Selain itu, usaha dibuat untuk mengenal pasti kumpulan makrofitmanayang menunjukkan tindakbalas paling kuat terhadapfaktor-faktorini. Penentuanfaktor-faktor tersebut akan membenarkan pengambilan tindakan perlindungan terhadap tasik. Tasik Gtębokie Uścimowskie terletak di bahagian barat Daerah Danau Łęczna-Włodawa (Poland). Ia adalah badan air eutrofik dengan luas permukaan 20.5 ha dan kedalaman maksimum $7.1 \mathrm{~m}$. Tasik Gtębokie Uścimowskie adalah tasik kecil dan dangkal yang terdiri daripada habitat yang pelbagai untuk makrofit. Lereng litoral, lereng zon penampan, dan tanah zon penampan memberi kesan terbesar terhadap kepelbagaian makrofit di dalam tasik. Peningkatan nilai pemboleh ubah ini mempengaruhi ciri-ciri seperti biojisim helofit, jarak helofit, dan kedalaman kehadiran makrofit hingga tahap yang paling besar. Arah angin, yang mempengaruhi bilangan spesies nimfa, juga sangat berkait. Pemboleh ubah penglihatan cakera Secchi mempunyai pengaruh paling kuat pada makrofit yang tenggelam. Sebagai peraturan, di tasik yang dikaji, jika zon dikembangkan secara terburu-buru, perkembangan makrofit yang tenggelam adalah terbatas. Perkembangan yang kurang baik secara terburu-buru akan disertai dengan variasi yang lebih besar antara makrofit yang tenggelam.

Kata kunci: Faktor abiotik; makrofit; morfologi spesies; pembezaan; tasik cetek

\section{INTRODUCTION}

The lake, like every ecosystem, is a network of mutual dependencies between the abiotic environment and the organisms inhabiting it. Many classifications of lakes exist depending on the group of features distinguishing them from one another, such as trophy, morphometric traits and origin. Such classifications also concern various groups of organisms occurring in particular types of lakes, including macrophytes. Macrophytes are aquatic plants whose presence, absence, or specific structure allow to indicate a specific type of lake. The distribution of macrophytes, and their composition, morphological characteristics, and biomass values, however, can be subjected to considerable fluctuation within a single, even small lake. Aquatic plants are essential for obtaining good ecological status of aquatic ecosystems. Therefore, it is necessary to preserve such communities in freshwaters (Bornette \& Puijalon 2011; Murphy 2002).

The analysis of the effect of various factors on the development of features of aquatic plants, or assessment of the ecological status of a lake usually generalizes such 
factors to obtain a single answer about the state of the lake (good or bad). Will averaging such information permit proper assessment and then protection of water reservoirs? What factors primarily determine the architecture of macrophytes, their species richness, and quantitative structure within a lake?

Factors considered the most important for the occurrence and development of macrophytes in lakes include hydrology, nutrient availability from sediments and water (Thiebaut et al. 2002; Xie et al. 2005), light conditions (Squires et al. 2002; Tavechio \& Thomaz 2003), climatic factors, particularly wind (Keddy 1983) and temperature (Lacoul \& Freedman 2006; Rooney \& Kalff 2000), biological interactions (Ervin \& Wetzel 2003; Van den Berg et al. 1998), and anthropogenic influences such as invasive species, pollution (Lacoul \& Freedman 2006), and land use in the buffer zone (Alahuhta et al. 2014; Sender \& Grabowski 2016).

This study concerned a small shallow lake. The objective of the study was to identify factors that may most significantly affect the quality and quantity structure of macrophytes. Moreover, the study involved the analysis of the diversity of such factors within the lake, and their impact on macrophytes, as well as an attempt to indicate which group of macrophytes showing the strongest response, and in what form the response (enriching diversity, disappearing or displacing other groups of plants). The determination of such factors will permit taking protective measures regarding the lake.

\section{MATERIALS AND METHODS}

Lake Głębokie Uścimowskie is located in the western part of the Łęczna-Włodawa Lake District (Poland). It is an eutrophic water body with a surface area of 20.5 ha and maximum depth of $7.1 \mathrm{~m}$ (Radwan \& Kornijów 1998). The lake is located in an agricultural area where arable land accounts for approximately $70 \%$ of the catchment basin. The lake is fed by water coming from surface and underground runoffs. It has neither an inflow nor outflow. The shore zone of the lake was clearly diversified in terms of use. This provided the basis for designating four study sectors: I - peat (boggy areas), II - rural (with rural buildings), III - agricultural (agricultural areas), and IV - bushy, referred to as forest in the paper. Within each sector, the study was conducted in two transects running $150 \mathrm{~m}$ from the shoreline towards the land, and from the shore towards the pelagic zone. The selection of two transects allowed for a more detailed analysis of differences even within the analysed sector (Figure 1).

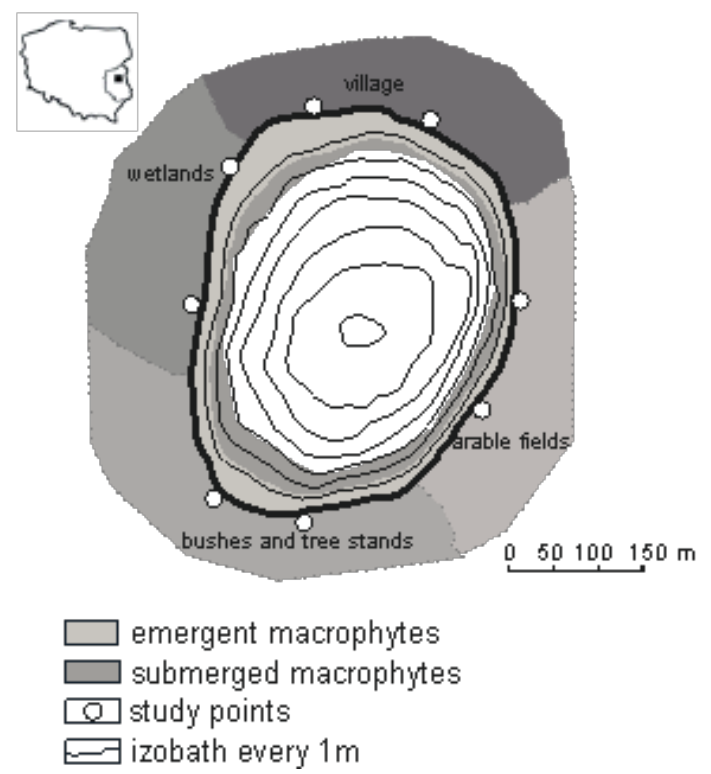

FIGURE 1. Location of the investigated lake, transects based on land use in the buffer zone and range of macrophyte occurrence

The analysed features of the lake and the coastal zone included slope of the littoral zone (\%), slope of the buffer zone (\%o) (Choiński 1995), land use in the boundary zone, and range of the $2.5 \mathrm{~m}$ isobath (software ArcMap 10.5.1). 
Wind direction and speed were also analysed based on data from a wind radar made available by www.skyradar. pl. Data were collected daily for a period of four months (from May to August during two years of research).

The slope of the littoral zone (x) was calculated based on the following formula (1):

$$
x=\frac{\mathrm{h}}{\mathrm{d}} \cdot 100 \%
$$

where $\mathrm{h}$ is the height change, and $\mathrm{d}$ is the distance (horizontal).

The slope of the buffer zone is calculated according to the following formula (2):

$$
i=\frac{h_{2}-\mathrm{h}_{1}}{\mathrm{~d}} \cdot 100 \% 0
$$

where $h_{1}$ and $h_{2}$ are heights of the given points ASL; $d$ is horizontal distance between given points; and $i$ is average slope.

In each of the transects, physical and chemical properties of water and sediments were analysed, including measurements of Secchi disk visibility (m), water $\mathrm{pH}(\mathrm{pH}), \mathrm{P}, \mathrm{P}-\mathrm{PO}_{4}$ and $\mathrm{N}-\mathrm{NO}_{3}$ concentration in water, as well as $\mathrm{C}$ org, $\mathrm{P}_{-} \mathrm{PO}_{4}$, and $\mathrm{N}-\mathrm{NH}_{4}$ in sediments. Material for the determination of physical-chemical water parameters was collected. The $\mathrm{pH}$ and water visibility were determined for each sample. Water parameters were analysed by means of a Secchi disc and a digital $\mathrm{pH}$ meter (CP-215 Elmetron). Material for the identification of other physical-chemical parameters of water and sediments was collected every two months in 2016 and 2017. Ion concentration, including orthophosphate, nitrate, and carbon was determined in the samples. The analyses of the parameter were performed according to standard methods (Hermanowicz et al. 1976).

The analysis of macrophytes was carried out in three groups, namely emerged, floating, and submerged. The analysis covered the distribution, determination of the maximum range of their occurrence (depth and width of individual plant belts), and qualitative and quantitative compositions (number of species and communities, density of emerged, biomass and domination in biomass). The analysis of macrophyte communities was based on a phytosociological relevé, i.e. the determination of all plant species occurring within the community (Matuszkiewicz 2008).

The Shannon-Wiener index of general diversity (H') was determined according to Shannon and Weaver (1963) as follow (3):

$$
\mathrm{H}^{\prime}=-\sum \text { pi ln pi }
$$

where $\mathrm{pi}=\mathrm{ni} / \mathrm{n}$, ni is the number of $\mathrm{i}$-species; and $\mathrm{n}$ is total density/biomass of individuals in the phytocoenosis.
Mapping of individual phytocoenoses was based on an aerial photograph and bathymetric map of the lake (at a scale of 1:25,000) from which the distribution and surface inhabited by macrophytes were determined in ArcMap10.5.1 software. The following indicators were used in the biocenotic analysis of macrophytes:

Species density index $(G)$ (Kasprzak \& Niedbała 1981) was calculated as (4):

$$
G=\frac{n_{g}}{S}
$$

where $\mathrm{n}_{\mathrm{g}}$ is species number; and $\mathrm{S}$ is sampling surface.

Species dominance (D\%) (Kasprzak \& Niedbała 1981) was calculated as (5):

$$
D=\frac{n_{i}}{N} \times 100 \%
$$

where $\mathrm{n}$ is biomass of species; and $\mathrm{N}$ is total biomass of species in the studied transect.

The similarity of the macrophytes occurring in particular transects of the lake was assessed. The analysis of the quality similarity by means of the Kulczyński pattern given by Szafer and Zarzycki (1972) was applied,

$$
Q=\frac{2 c}{a+b} \times 100 \%
$$

where Q is similarity coefficient; a is number of species occurring in catchment type $\mathrm{I}, \mathrm{b}$ is number of species occurring in catchment type II, c is number of common species found in both types of catchment.

The quantitative similarity was calculated according to the Marczewski and Steinhaus (1959) pattern (7):

$$
P=\frac{\sum_{i=1} \frac{a}{b_{i}}}{n}
$$

where $\mathrm{P}$ is similarity of the types of compared catchments; $\mathrm{n}$ is total number (biomass) of the species of the catchment types compared; a is biomass of catchment type I elements (in \%); and b is biomass of the catchment type II elements (in \%).

\section{STATISTICAL ANALYSIS}

The statistical significance of differences in macrophyte communities based on biomass, species richness, colonisation depth, and coverage between transects was assessed by means of t-test or two-way repeated measures ANOVA. The normality of the data distribution was analysed with the application of a Shapiro-Wilk test. The non-parametric Kruskall-Wallis test was used when the hypotheses for the parametric test were not confirmed. All data analyses were carried out in Statistica 13 programme. The Principal Component Analysis (PCA) was performed. 
The data set was first subjected to detrended correspondence analysis (DCA) which showed a firstaxis gradient length of 0.65 in standard deviation units. Therefore, we decided to apply linear methods of ordination as principal component analysis (PCA). PCA with standardised environmental variables was used to visualise patterns of environmental variation across lake transects. Prior to the analysis, redundant environmental variables (with linear correlation coefficient $r>0.7$ ) were omitted to avoid collinear rite (Blanchet et al. 2008). Further analysis took the following environmental variables into account - SD, PBC, PWC, PtWC and NWC for water quality, and WD, LS, BZS and BZM for land use in the buffer zone. Significant PCA axes were selected with both Kaiser-Gutman criterion and the broken-stick model (Borcard et al. 2011).

\section{RESULTS}

\section{MORPHOMETRIC AND PHYSICAL-CHEMICAL CHARACTERISTICS}

The development of the analysed transects of Lake Głębokie took four different forms: as a peat bog, rural development, arable fields, and shrubs (forest). Secchi disc visibility ranged from $0.5 \mathrm{~m}$ in transect II to $0.9 \mathrm{~m}$ in transect I. The slope inclination of the littoral zone was significantly varied from $2.4 \mathrm{~m}$ in transect II to $3.5 \mathrm{~m}$ in transect III. The largest differences in elevation in the buffer zone occurred in transect IV, while the peatland area (transect I) was characterised by a marked decrease in the area (Table 1).

TABLE 1. Morphometric and physical-chemical characteristics of the study transects

\begin{tabular}{|c|c|c|c|c|c|}
\hline & Transect feature & I & II & III & IV \\
\hline & Usage type of coastal zone & Swamp/bog & Rural buildings & Arable fields & Bushes/forest \\
\hline & Range of the $2.5 \mathrm{~m}$ isobath & 67 & 70 & 33 & 73 \\
\hline & Visibility of Secchi's disc m & 0.9 & 0.5 & 0.8 & 0.7 \\
\hline & Slope of the littoral zone $\%$ & 2.56 & 2.61 & 3.52 & 2.42 \\
\hline & Slope of buffer zone \%o & -10.9 & 17.5 & 22.9 & 37.1 \\
\hline & Direction of transect & $\mathrm{S} \rightarrow \mathrm{N}$ & $\mathrm{N} \rightarrow \mathrm{S}$ & $\mathrm{E} \rightarrow \mathrm{W}$ & $\mathrm{W} \rightarrow \mathrm{E}$ \\
\hline & Wind direction & Western & Northwest & Western & Southwestern \\
\hline & $\mathrm{pH}$ & 8.28 & 8.7 & 8.87 & 9.32 \\
\hline & Oxygen saturation of water $\%$ & 64.6 & 71.3 & 77.3 & 52.3 \\
\hline \multirow{3}{*}{ 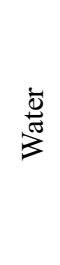 } & P og & 0.16 & 0.17 & 0.18 & 0.15 \\
\hline & $\mathrm{P}^{-\mathrm{PO}_{4}}$ & 0.03 & 0.04 & 0.05 & 0.01 \\
\hline & $\mathrm{N}-\mathrm{NO}_{3}$ & 0.5 & 0.7 & 0.6 & 0.3 \\
\hline \multirow{3}{*}{ 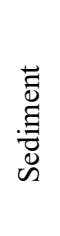 } & $\mathrm{C}$ org & 14.7 & 14.43 & 11.61 & 13.2 \\
\hline & $\mathrm{P}-\mathrm{PO}_{4}$ & 6.67 & 5.5 & 6.05 & 6.14 \\
\hline & $\mathrm{N}-\mathrm{NH}_{4}$ & 2.26 & 2.15 & 2.07 & 2.14 \\
\hline
\end{tabular}




\section{FLORISTIC DIVERSITY}

The entire littoral of Lake Głębokie included 28 plant communities (Table 2). The number of macrophyte phytocoenoses was clearly differentiated in individual transects. The highest number of communities (14) developed in transect I, with a peat bog as an adjacent area, and the lowest (8) was in transect IV with an adjacent forest area. Relatively high phytocoenotic diversity based on Shannon-Wiener index occurred in transects I and III (0.95 and 0.93 respectively) (Table 2).

The majority of the analysed features of macrophytes were variable within the studied lake. The highest depth of macrophyte occurrence in Lake Głębokie was 2.9 $\mathrm{m}$, and the extent of the littoral zone $(111.5 \mathrm{~m})$ was the highest in transect IV. The lowest depth macrophytes was determined for transect II $(1.8 \mathrm{~m})$, whereas the narrowest zone of littoral occurred in transect III. The widest belt of rushes had developed in transect I, and the smallest was in transect III (Figure 2; Table 3).

The largest number of submerged macrophyte species as well as floating leaf plants was found in transects I ( 8 and 4 species) and III ( 7 and 4 species). In the remaining transects, the largest group was emerged macrophytes (7 species in each transect) (Table 3 ).

The total biomass of macrophytes varied in particular parts of Lake Głębokie. The highest value was found in transect IV $\left(558 \mathrm{~g} / \mathrm{m}^{2}\right)$, and the lowest in transect II $\left(397 \mathrm{~g} / \mathrm{m}^{2}\right)$. Different biomass was determined among particular groups of macrophytes. Emergent

macrophytes predominated in biomass in transects I and II, while in transects III and IV slightly higher biomass values concerned submerged macrophytes. The share of nymphaeids in biomass was negligible in all transects (Table 3).

Among the emergent macrophytes, Phragmitetum australis dominated in biomass in all transects. Among the elodeids, Ceratophyllum demersum dominated in biomass in transects III and IV, Elodea canadensis in transect II, and Potamogeton pectinatus in transect I (Table 3). In terms of floristic composition, the highest similarity of $64 \%$ was found in macrophyte species composition in transects II and III. The smallest similar composition of macrophytes was in transects I and III (only $36 \%$ ) (Table 4). Based on qualitative analyses of macrophytes, the highest similarity occurred between transects III and IV, equalling 68\%, and the smallest was between I and III, only 29\% (Table 4).

The variability of distribution of the analysed features in Lake Głębokie was particularly determined by littoral slope, buffer zone slope, and buffer zone management. An increase in the value of these variables affected features such as helophytes biomass, helophytes range, and depth of macrophyte occurrence to the greatest degree. A strong negative correlation was determined for wind direction that had the strongest effect on the number of nymphaeid species. Secchi disc visibility had the strongest effect on submerged macrophytes (Figure 3).
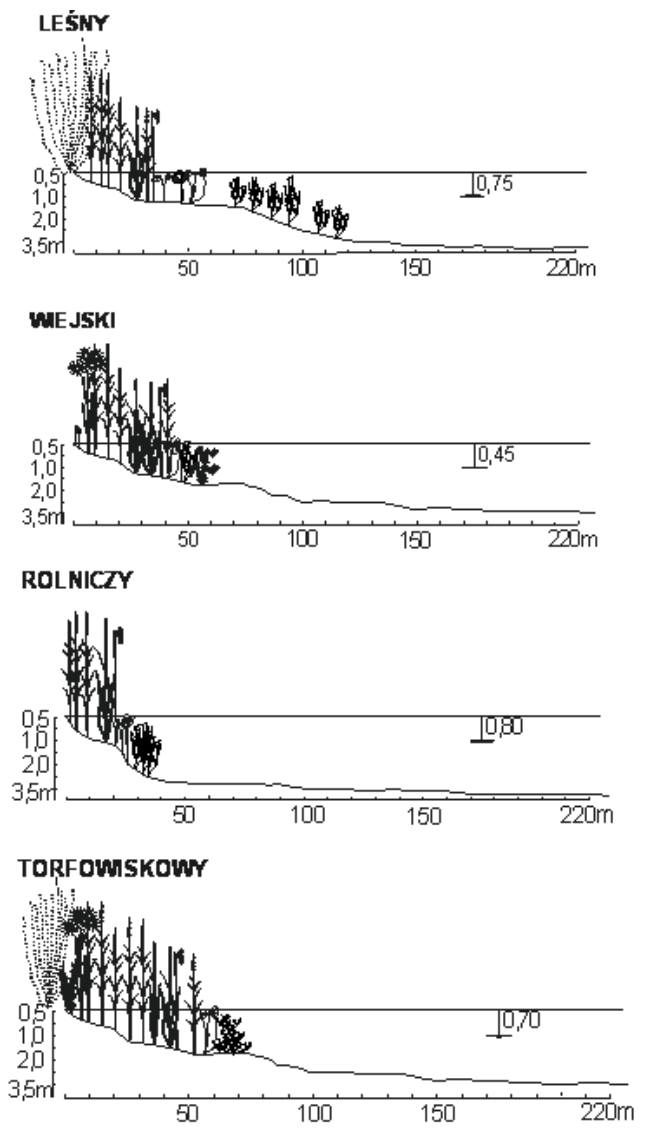

FIGURE 2. Distribution and species composition of macrophytes in particular transects 


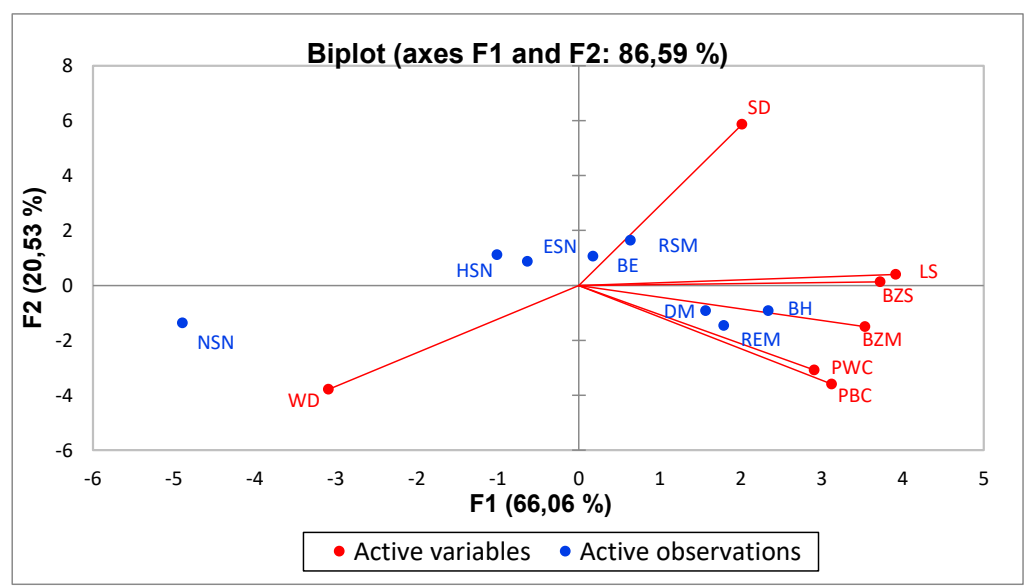

FIGURE 3. PCA analysis. RSM - range of submerged macrophytes, BE biomass of elodeids, $\mathrm{BH}$ - biomass of helophytes, HSN - helophytes species number, NSN - nympheids species number, ESN - elodeids species number, $\mathrm{DM}$ - depth of macrophytes occurrence, $\mathrm{SD}$ - secchi disc visibility, $\mathrm{PBC}-\mathrm{PO} 4$ bottom content, PWC - PO4 water content, WD - wind direction, REM - range of emergent macrophytes, LS - Littoral slope, BZS - buffer zone slope, and BZM - buffer zone management

TABLE 2. Floristic composition and diversity index at particular study transects

$$
\text { Research sectors }
$$$$
\text { I }
$$$$
\text { II }
$$$$
\text { III }
$$

Vegetation community

Cl. Potametea R. Tx. et Preisg. 1942

O. Potametalia Koch 1926

All. Potamion Koch 1926 em. Oberd. 1957

Potametum pectinati Carstensen 1955

Myriophylletum spicati Soe 1927

Elodeetum canadensis (Pign. 1953) Pass. 1964

Ceratophylletum demersi Hild 1956

Potametum acutifolii Segal 1961

All. Nymphaeion Oberd. 1953

Nupharo-Nymphaeetum albae Tomasz. 1977

Nymphaeetum candidae Miljan 1958

$+\quad+$

Polygonetum natantis Soó 1927

Potametum natantis Soó 1923 
Caricetum ripariae Soó 1928

Caricetum rostratae Rübel 1912

Salicetum pentandro-cinerea (ALMQ. 1929) PASS.

1961

Number of community

14

9

11

8

Shannon-Wiener index

0.95

0.82

0.93

0.75

TABLE 3. Analysed macrophyte features in individual transects

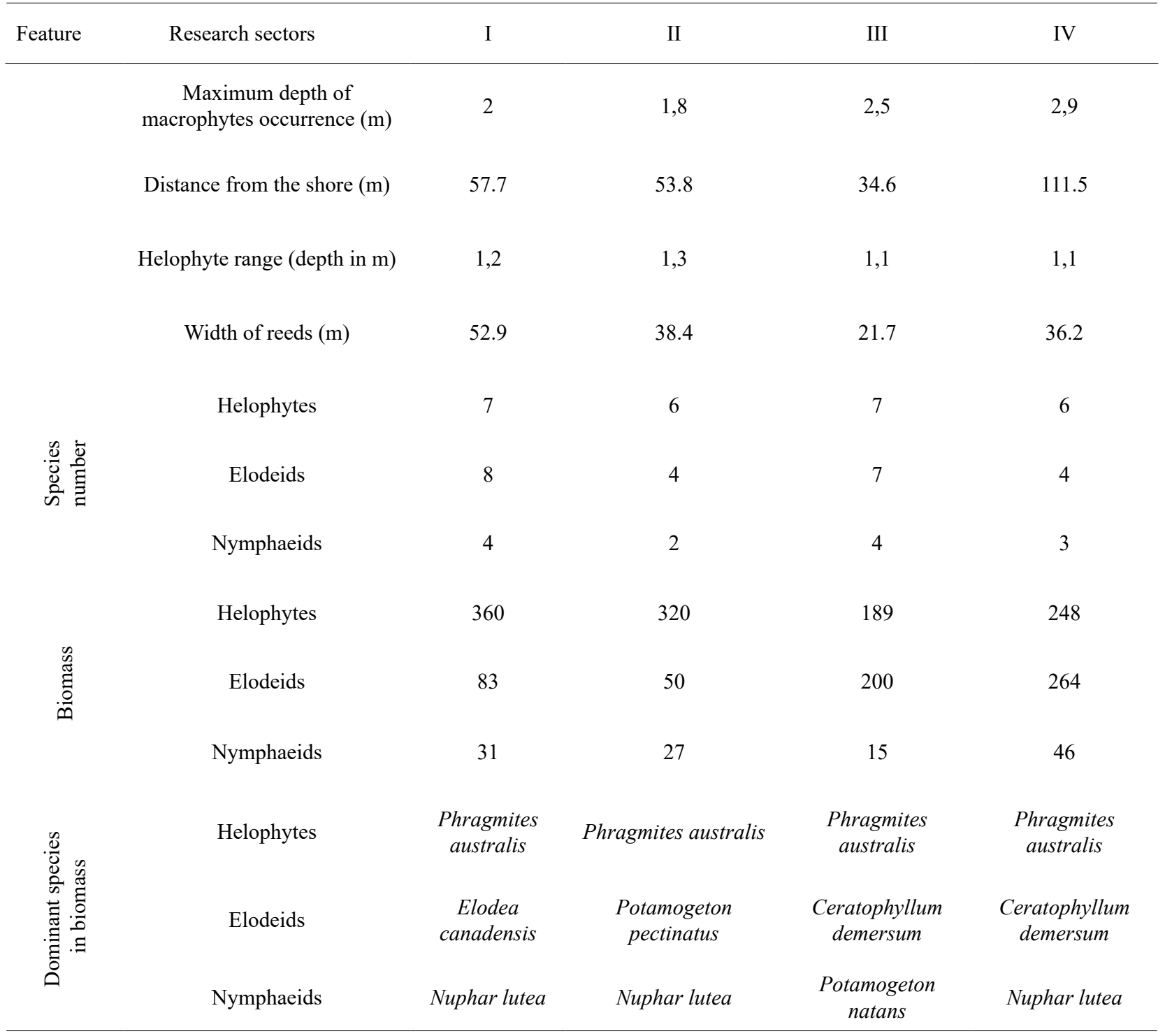


TABLE 4. Qualitative (Q)/quantitative (P) similarity (\%) of macrophytes in the transects

\begin{tabular}{lcccc}
\hline & I & II & III & IV \\
\hline I & - & $47 / 61$ & $36 / 29$ & $55 / 32$ \\
II & - & $64 / 42$ & $38 / 31$ \\
III & & & \\
IV & & - & $62 / 68$ \\
\hline
\end{tabular}

\section{MORPHOLOGY OF SELECTED SPECIES}

The analysed $P$. australis shoots showed variability within the highlighted zones of Lake Głębokie. Their highest density occurred in transect I $\left(57 \mathrm{ind} / \mathrm{m}^{2}\right)$, and the lowest density, equalling $46 \mathrm{ind} / \mathrm{m}^{2}$, in transect III. The mass of shoots and their height were the highest in transect I, and the lowest was in transect III (Table 5). All the analysed Phragmites features were higher at study sites located near land than those in open water, and the differences were statistically significant $\left(\mathrm{F}_{1.16}=5.75 ; \mathrm{p}\right.$ $<0.023)$. The smallest differences between the study sites (open water and land) were found in transect IV. They were not statistically significant $\left(\mathrm{F}_{2.30}=1.09 ; \mathrm{p}<0.35\right)$.

Both the mass of plant and the length of $C$. demersum reached the highest values in transect III.
Their shoots were also branched the strongest there. The poorest Ceratophyllum developed in transect II (Table 6). The differences were statistically significant $\left(\mathrm{F}_{1.16}=5.75\right.$; $\mathrm{p}<0.023$ ).

The distribution of feature variability of the two analysed macrophyte species in Lake Głębokie was primarily determined by littoral slope and buffer zone slope. An increase in the value of the variables affected features of reed such as density, diameter, and height the strongest. Visibility of Secchi's disc (SD) was also highly negatively correlated. It had the strongest effect on the mass of $C$. demersum. The PWC, PWB and NWC variables had the strongest influence on features of reed such as SIN, NPP and LN (Figure 4).

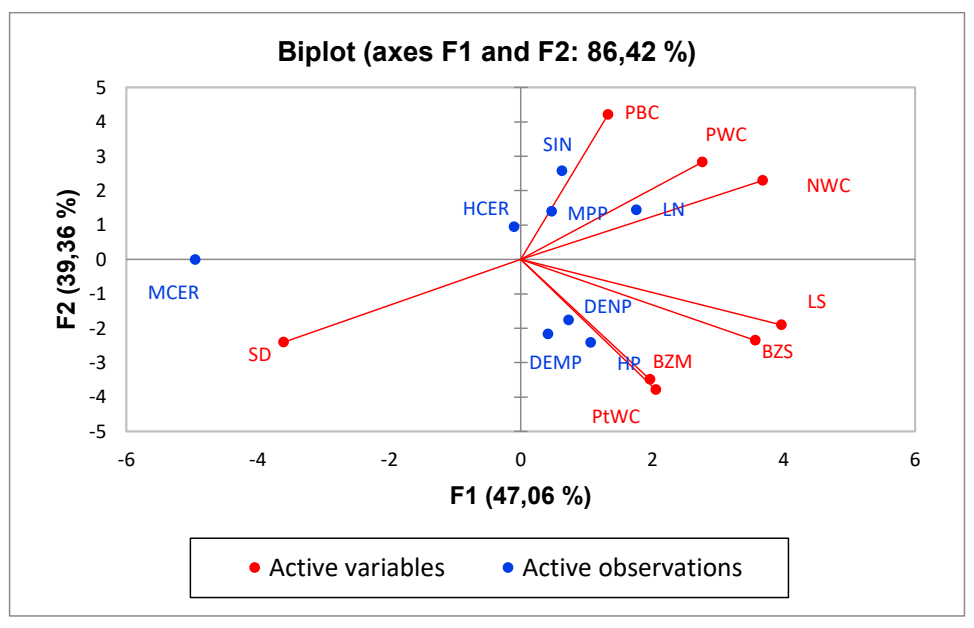

FIGURE 4. PCA analysis. SD - secchi disc visibility, PBC - PO4 bottom content, PWC - PO4 water content, LS - Littoral slope, BZS - buffer zone slope, BZM - buffer zone management, PtWC - Ptot water content, NCW - NH4 water content, DENP - density of reed, MPP - mass of reed, HP - height of reed, LN

- number of leaves, DEMP - diameter of reed, SIN - share of inflorescence, MCER - mass of Ceratophyllum, and HCER - length of Ceratophyllum 
TABLE 5. Analysed morphological features of Phragmites australis at individual study sites

\begin{tabular}{|c|c|c|c|c|c|c|c|c|}
\hline Transect & \multicolumn{2}{|c|}{ I } & \multicolumn{2}{|c|}{ II } & \multicolumn{2}{|c|}{ III } & \multicolumn{2}{|c|}{ IV } \\
\hline $\begin{array}{c}\text { Feature } \\
\text { Study site }\end{array}$ & Water & Shore & Water & Shore & Water & Shore & Water & Shore \\
\hline Density $\left(\mathrm{m}^{2}\right)$ & 48 & 66 & 45 & 63 & 38 & 55 & 49 & 50 \\
\hline Mass of shoot $(\mathrm{g})$ & 10.5 & 21.4 & 12.1 & 14.1 & 7.7 & 15.0 & 18.3 & 18.5 \\
\hline Height (m) & 1.7 & 2.6 & 1.9 & 2.1 & 1.5 & 2.0 & 2.2 & 2.3 \\
\hline Number of leaves (ind.) & 4.9 & 7.3 & 9.9 & 10.7 & 5.2 & 10.4 & 11.7 & 12.6 \\
\hline Diameter of shoot $(\mathrm{cm})$ & 5.2 & 7.9 & 5.6 & 5.9 & 6.1 & 7.1 & 8.0 & 9.3 \\
\hline $\begin{array}{l}\text { Length of inflorescence } \\
(\mathrm{cm})\end{array}$ & 19.7 & 23.8 & 21.0 & 23.2 & 13.0 & 15.0 & 18.5 & 19.8 \\
\hline $\begin{array}{l}\text { Share of shoots with } \\
\text { inflorescence }(\%)\end{array}$ & 50 & 98 & 40 & 85 & 20 & 60 & 26 & 86 \\
\hline
\end{tabular}

TABLE 6. Analysed morphological features of Ceratophyllum at study transects

\begin{tabular}{lcccc}
\hline Feature & I & II & III & IV \\
\hline Mass of shoot $(\mathrm{g})$ & 19,7 & 12,4 & 33,7 & 20,7 \\
Height $(\mathrm{m})$ & 1,4 & 1,3 & 1,7 & 1,5 \\
Type of stem & $\begin{array}{c}\text { Strongly } \\
\text { branched }\end{array}$ & Branched & $\begin{array}{c}\text { Very strongly } \\
\text { branched }\end{array}$ & $\begin{array}{c}\text { Strongly } \\
\text { branched }\end{array}$ \\
\hline
\end{tabular}

\section{DISCUSSION}

The diversity of macrophytes in large lakes is more obvious (natural) due to a variety of factors occurring in them, including the surface area, development, and length of the shoreline (Feldman \& Nöges 2007). Small and shallow lakes should be more homogeneous in terms of biotic and abiotic factors due to the occupied surface area. Small lakes are more dependent on their surroundings (Bedla \& Misztal 2014). Factors that affect most significantly macrophytes are habitat conditions 
such as the slope of the lake bottom, the surrounding area, and land use in the area (Alahuhta et al. 2012; Beck et al. 2010; Marzin et al. 2012).

Macrophytes are characterised by great flexibility in adapting to environmental conditions found in aquatic ecosystems. Their occurrence is significantly influenced by light conditions, water temperature, and content of biogenic compounds in lake water and in bottom sediments (Dar et al. 2014; Hutchinson 1975; Spence 1982). The presence of macrophytes in lakes, especially submerged ones, depends primarily on the light conditions prevailing in the water (Bornette \& Puijalon 2011; Dar et al. 2014; Duarte et al. 1986; Sculthorpe 1967; Weisner et al. 1997). The maximum limit of plant occurrence in lakes of the temperate climate zone is determined by the penetration depth of $1 \%$ of the surface light falling on the water surface (Sculthorpe 1967). Macrophytes can occur at greater depths, indicated by water transparency measured by the Secchi disc. It involves the occurrence of a phenomenon called the 'escape effect' (Scheffer et al. 1992). In the studied transects, Secchi disc visibility, defining the euphotic zone, did not coincide with the lower limit of occurrence of compact plant formations. Macrophytes showed a range larger than the visibility of the Secchi disc. Similar dependencies between the distribution of macrophytes and light conditions were found in shallow lakes in the Netherlands (Scheffer et al. 1992). In the eutrophic lakes of the Masurian Lake District and Drawieński National Park, macrophytes occurred at depths of up to $3 \mathrm{~m}$ and even up to $5.5 \mathrm{~m}$ (Kraska at al. 2002; Ozimek \& Kowalczewski 1984). Similarly, high values were recorded in the hypertrophic Lake Kirkkojarvi in Finland (Nurminen \& Horppila 2002). In the studied Lake Głębokie, it was clearly diversified ranging from 1.8 to $2.9 \mathrm{~m}$. The value of this factor was the most influenced by the nutrient content and morphometry of the lake and shoreline zone. Moreover, the light conditions clearly correlated with the range of occurrence of $C$. demersum.

A factor limiting the light conditions in the lake is its shading (Ali et al. 2011; Sender 2016). In Lake Głębokie, the influence of this factor was determined in transect IV, surrounded by trees and shrubs. The largest range of emerged macrophytes occurred there because the morphological conditions of this part of the lake favoured their development, though the biomass and density were low. Helophytes are less sensitive to light conditions of lakes (Alahuhta et al. 2014). This group of plants, however, is more sensitive to fluctuations in water levels (Feldman \& Nõges 2007) which were of less importance for this lake due to the duration of the study.

Helophytes in Lake Głębokie in years 20162017 occupied approximately $67 \%$ of the phytolittoral area. It developed in the form of an irregular belt. The average width of the helophyte belt in other lakes of the Łęczyńsko-Włodawskie Lake District was 8.12 $\mathrm{m}$ (Sender 2009) while in the lakes of the Jorka River system reached $9.2 \mathrm{~m}$ (Szajnowski 1983). In the studied lake, rushes reached a width of up to $39.7 \mathrm{~m}$. In the 1990's, the belt was $32.1 \mathrm{~m}$ wide (Sender 2004). This phenomenon suggests progressive processes of overgrowing of the lake. At that time, among submerged macrophytes in Lake Głębokie, Elodeetum canadensis was predominant. In Poland, the numerous occurrence of this phytocoenosis is known from the slightly eutrophic lakes of the Masurian Lake District and the southern part of Kujawy (Ciecierska 2000). Elodea canadensis currently evidently regressed from the studied lake. It was also replaced by a species alien to Polish waters, namely C. demersum (Cook \& Urmi-König 1985; HowardWilliams 1993). Ceratophyllum demersum is native to North America. It now has a worldwide distribution. Ceratophyllum demersum can be found in different types of water ecosystems with moderate to high nutrient levels (Fukuhara et al. 1997). In Poland, as well as overseas, C. demersum has performed well in eutrophic waters (Coffey \& Clayton 1988), though it may be able to invade a wider variety of habitats than previously thought. In the studied lake, it was the most abundant only in the first transect with peat land management.

The area occupied by aquatic vegetation is of great importance for the functioning of the entire aquatic ecosystem (Wang et al. 2017). In Lake Głębokie, the phytolittoral occupied $14.1 \%$ of the lake's surface in the 1990's. In 2011 the value was 29.17\% (Sender 2012), while within the analysed period it equalled $32.2 \%$. In Masurian lakes, depending on the lake's trophic status, the coverage ranged from $42.4 \%$ in the mesotrophic Lake Majcz Wielki to $58 \%$ in the eutrophic Lake Zełwążek (Ozimek 1983). In the lakes of the Suwałki Lake District, the surface area of the phytolittoral ranged from $15 \%$ to even 95\% (Ozimek \& Rybak 1993).

Macrophyte biomass was largely variable in the studied lake, depending on the transect. The distribution and diversity of macrophytes was dependent on the shape of the shoreline zone and its management. The largest total biomass occurred in the forest transect $(0.5 \mathrm{t} / \mathrm{ha})$, where the concentrations of the analysed nutrients in the water were the lowest. The lowest biomass values were determined in the transect with rural buildings $(0.3 \mathrm{t} /$ ha), where the concentration of nutrients was relatively high. Macrophyte biomass values were similar to those found in the lakes of the Masurian Lake District, where they ranged from $0.7 \mathrm{t} / \mathrm{ha}$ in the mesotrophic Lake Majcz Wielki to $0.6-1.9 \mathrm{t} / \mathrm{ha}$ in the eutrophic Lakes Śniardwy and Warniak (Pieczyńska \& Ozimek 1976).

In the transects with peat bog and rural buildings, emerged macrophytes dominated in biomass while 
submerged populations reached low values. In the other two transects, submerged macrophytes slightly predominated. This suggests the occurrence of the phenomenon of equality differences in abundance among macrophyte taxa (Fargione \& Tilman 2002; Sender et al. 2015). In the transect I, where a decrease in the area was the lowest, there was also high species diversity among submerged macrophytes, but their biomass was small.

The source of nutrients for macrophytes is both water and sediment (Kłosowski 1985; Kłosowski \& Tomaszewicz 1988). It remains unknown, however, what exactly constitutes their main source (Barko \& Smart 1981; Carter et al. 1991; Hutchinson 1975; Reedyk et al. 2001; Tomaszewicz 1987). Both the content of nutrients and organic carbon in bottom sediments of the studied lake showed a clear differentiation between transects. This fact may explain the occurrence of varied phytocoenoses within a small space (Tomaszewicz 1987).

The ecological character of the catchment affects the qualitative and quantitative structure of macrophytes inhabiting the littoral zone. The most frequently observed effects include the reduction of macrophyte distribution and biomass, as well as changes in their species composition, spatial distribution, and diversity (Naiman \& Decamps 1990; Pieczyńska \& Jachimowicz-Janaszek 1988). It is primarily associated with land use in the lake catchment. The degree of influence of the catchment on the lake depends on the density of the vegetation covering the shore, affecting surface runoff. Climatic, physiographic, geological conditions such as slope inclination, groundwater fluctuation, and type of soil and sediment also have a considerable impact on the structure of macrophytes (Hongve 1999; Zieliński et al. 1999).

As a rule, the highest species diversity as well as biomass occurred among emergent and submerged macrophytes in the littoral of the peat catchment. The catchment of this type plays an important role in supplying water bodies with organic matter, and particularly humic acids (Kraska et al. 2002). This regularity occurs in the period of lowering the water level causing drainage of these catchments and meliorations (Górniak 1996; Górniak 1999). The lowest biomass values but with high species diversity occurred in catchments with arable fields. In the agricultural catchment, which usually has a large flow of nutrients caused by fertilisation (Bartoszewicz \& Ryszkowski 1996), a large decline in the littoral zone of Lake Głębokie occurred, preventing its settling in bad light conditions. The lowest species diversity of submerged and emergent macrophytes was found in the forest catchment, though it reached high biomass values. Less nutrients flow into lakes from catchments with such land use because they are not very rich in these elements. Moreover, they are dominated by underground water supply (Górniak 1999; Kufel 1999; Zdanowicz 1994).
In some types of catchments, the phenomenon of 'replacement' of emergent and submerged macrophytes has appeared. The biomass of submerged macrophytes was observed to be smaller in the transects where the biomass of helophytes was high. In transects where the helophyte biomass decreased, the biomass of submerged macrophytes slightly increased. It can be assumed that nutrients supplied from the catchment are mostly retained by helophytes. The retention of nutrients is greater when the littoral zone is more settled by vegetation, and is directly proportional to the biomass of macrophytes found in the zone (Moshiri 1993).

\section{CONCLUSION}

Despite their small surface area, shallow lake constitutes a diverse habitat for macrophytes. The littoral slope, buffer zone slope, and buffer zone land use had the greatest impact on the macrophyte diversity of the small and shallow Lake Głębokie. An increase in the value of these variables affected features such as helophyte biomass, helophyte range, and depth of macrophyte occurrence to the greatest degree. Wind direction, which influenced the number of nympheid species, was also highly correlated. Visibility of Secchi's disc variable had the strongest influence on submerged macrophytes. Generally, in the studied lake, if the rushes zone was well developed, the development of submerged macrophytes was limited. Poorly developed rushes were accompanied by greater variability among submerged macrophytes.

\section{REFERENCES}

Alahuhta, J., Kanninen, A., Hellsten, S., Vuori, K.M., Kuoppala, M. \& Hämäläinen, H. 2014. Variable response of functional macrophyte groups to lake characteristics, land use, and space: implications for bio-assessment. Hydrobiologia 737(1): 201-214.

Alahuhta, J., Kanninen, A. \& Vuori, K.M. 2012. Response of macrophyte communities and status metrics to natural gradients and land use in boreal lakes. Aquatic Botany 103: 106-114.

Ali, M.M., Hassa, S.A. \& Shaheen, A.M. 2011. Impact of riparian trees shade on aquatic plant abundance in conservation islands. Acta Botanica Croatica 70(2): 245-258.

Barko, J.W. \& Smart, R.M. 1981. Sediment-based nutrition of submersed macrophytes. Aquatic Botany 10: 339-352.

Bartoszewicz, A. \& Ryszkowski, L. 1996. Influence of shelterbelts and meadows on the chemistry of ground waters. In Dynamics of an Agricultural Landscape, edited by Ryszkowski, L., French, N. \& Kędziora, A. Poznań. Poznań Państwowe Wydawnictwo Rolnicze i Leśne. pp. 98-109.

Beck, M.W., Hatch, L.K., Vondracek, B. \& Valley, R.D. 2010. Development of a macrophyte-based index of biotic integrity for Minnesota lakes. Ecological Indicators 10(5): 968-979.

Bedla, D. \& Misztal, A. 2014. Zmienność chemizmu wód małych zbiorników wodnych o zróżnicowanej strukturze 
użytkowania terenów przyległych. Annual Set of Environment Protection 16: 421-439.

Blanchet, F.G., Legendre, P. \& Borcard, D. 2008. Forward selection of explanatory variables. Ecology 89(9): 26232632.

Borcard, D., Gillet, F. \& Legendre, P. 2011. Numerical Ecology with $R$. New York: Springer.

Bornette, G. \& Puijalon, S. 2011. Response of aquatic plants to abiotic factors: A review. Aquatic Sciences 73(1): 1-14.

Carter, V., Rybicki, N.B. \& Hammerschlag, R. 1991. Effect of submersed macrophytes on dissolved oxygen, $\mathrm{pH}$, temperature under different conditions of wind, tide and bed structure. Journal of Freshwater Ecology 6(2): 121-133.

Choiński, A. 1995. Zarys limnologii fizycznej Polski. Poznań: Wydaw. Naukowe UAM.

Ciecierska, H. 2000. Zróżnicowanie przestrzenne roślinności litoralu i otuliny wybranych jezior miejskich Pojezierza Mazurskiego. Rozprawy i Monografie. Uniwersytet Warmińsko-Mazurski w Olsztynie 34: 1-77.

Coffey, B.T. \& Clayton, J.S. 1988. Changes in the submerged macrophyte vegetation of Lake Rotoiti, Central North Island, New Zealand. New Zealand Journal of Marine and Freshwater Research 22: 215-223.

Cook, C.D. \& Urmi-König, K. 1985. A revision of the genus Elodea (Hydrocharitaceae). Aquatic Botany 21(2): 111-156.

Dar, N.A., Pandit, A.K. \& Ganai, B.A. 2014. Factors affecting the distribution patterns of aquatic macrophytes. Limnological Review 14(2): 75-81.

Duarte, C.M., Kalff, J. \& Peters, R.H. 1986. Patterns in biomass and cover of aquatic macrophytes in lakes. Canadian Journal of Fisheries and Aquatic Sciences 43: 1900-1908.

Ervin, G.N. \& Wetzel, R.G. 2003. An ecological perspective of allelochemical interference in land-water interface communities. Plant and Soil 256(1): 13-28.

Fargione, J. \& Tilman, D. 2002. Competition and coexistence in terrestrial plants. In Competition and Coexistence (Ecological Studies), edited by Sommer, U. \& Worm, B. Berlin: Springer.

Feldman, T. \& Nöges, P. 2007. Factors controlling macrophyte distribution in large shallow Lake Võrtsjärv. Aquatic Botany 87(1): $15-21$.

Fukuhara, H., Tanaka, T. \& Izumi, M. 1997. Growth and turion formation of Ceratophyllum demersum in a shallow lake in Japan. Japanese Journal of Limnology 58(4): 335-347.

Górniak, A. 1999. Rola hydrologii i charakteru zlewni w kształtowaniu chemizmu wód jezior. In. Górniak, A. Supraśl (ed.). Wspótczesne Kierunki Badań Hydrobiologicznych: Materiały Ogólnopolskiej Konferencji Naukowej. Białystok: Wydawnictwo Uniwersytetu w Białymstoku.

Górniak, A. 1996. Substancje humusowe i ich rola w funkcjonowaniu ekosystemów słodkowodnych. Doctoral dissertation, University of Warsaw (Unpublished).

Hermanowicz, W., Dožańska, W., Dojlido, J. \& Koziorowski, B. 1976. Fizyczno-Chemiczne Badanie Wody I Ścieków. Warszawa: Arkady.

Hongve, D. 1999. Production of dissolved organic carbon in forested catchments. Journal of Hydrology 224: 91-99.

Howard-Williams, C. 1993. Processes of aquatic weed invasions: The New Zealand example. Journal of Aquatic Plant Management 31: 17-23.
Hutchinson, G.E. 1975. Limnological botany. A Treatise on Limnology. 3rd edition. New York: Wiley.

Kasprzak, K. \& Niedbała, W. 1981. Wskaźniki biocenotyczne stosowane przy porządkowaniu i analizie danych w badaniach ilościowych. In Metody Stosowane w Zoologii Gleby, edited by Górny, M. \& Grum, L. Warszawa: Wyd. Naukowe PWN.

Keddy, P.A. 1983. Shoreline vegetation in Axe Lake, Ontario: Effects of exposure on zonation patterns. Ecology 64(2): 331-344.

Kłosowski, S. 1985. Habitat requirements and bioindicator value of main communities of aquatic vegetation in Northeast Poland. Polish Archives of Hydrobiology 32(1): 7-29.

Kłosowski, S. \& Tomaszewicz, H. 1988. Differentiation between habitats of Myriophyllum spicati Soó 1927 and Myriophylletum verticillati Soó 1927 phytocenoses in North-Eastern Poland. Acta Hydrobiologica 30(1-2): 225238.

Kraska, M., Piotrowicz, R., Szyper, H., Szeląg-Wasilewska, E., Gołdyn, R. \& Klimaszyk, P. 2002. Variability of trophic state and vegetation in lakes of Drawieński National Park (Northern Poland). Verhandlungen des Internationalen Verein Limnologie 28: 900-904.

Kufel, L. 1999. Transport pierwiastkow biogennych w zlewniach Mazurskiego Parku Krajobrazowego. In Funkcjonowanie i Ochrona Ekosystemów Wodnych na Obszarach Chronionych, edited by Zdanowski, B., Kamiński, M. \& Martyniak, A. Olsztyn: Wyd. IRŚ.

Lacoul, P. \& Freedman, B. 2006. Environmental influences on aquatic plants in freshwater ecosystems. Environmental Reviews 14(2): 89-136.

Marczewski, E. \& Steinhaus, H. 1959. O odległości systematycznej biotopów. Applicationes Mathematicae 4(3): 195-203.

Marzin, A., Archaimbault, V., Belliard, J., Chauvin, C., Delmas, F. \& Pont, D. 2012. Ecological assessment of running waters: Do macrophytes, macro-invertebrates, diatoms and fish show similar responses to human pressures?. Ecological Indicators 23: 56-65.

Matuszkiewicz, W. 2008. Przewodnik do Oznaczania Zbiorowisk Roślinnych Polski. Warszawa: Wydawnictwo Naukowe PWN.

Moshiri, G.A. 1993. Constructed Wetlands for Water Quality Improvement. Florida: Lewis Publish.

Murphy, K.J. 2002. Plant communities and plant diversity in softwater lakes of Northern Europe. Aquatic Botany 73(4): 287-324.

Naiman, R.J. \& Decamps, H. 1990. The Ecology and Management of Aquatic-Terrestrial Ecotones. United Kingdom: The Parthenon Publishing Group.

Nurminen, L.K. \& Horppila, J.A. 2002. A diurnal study on the distribution of filter feeding zooplankton: Effect of emergent macrophytes, $\mathrm{pH}$ and lake trophy. Aquatic Sciences 64(2): 198-206.

Ozimek, T. 1983. Biotic structure and processes in the lake system of r. Jorka watershed (Masurian Lakeland, Poland). $\mathrm{X}$. Biomass and distribution of submerged macrophytes. Ekologia Polska 31(3): 781-792. 
Ozimek, T. \& Rybak, J.I. 1993. Macrophytes of small water bodies of the Suwałki Landscape Park (North-Eastern Poland). Ekologia Polska 1(41): 157-171.

Ozimek, T. \& Kowalczewski, A. 1984. Long-term changes of the submerged macrophytes in eutrophic Lake Mikołajskie (North Poland). Aquatic Botany 19(1-2): 1-11.

Pieczyńska, E. \& Jachimowicz-Janaszek, A. 1988. Decomposition of Elodea canadensis Rich. in relation to size structure of particles. Polskie Archiwum Hydrobiologii 35(2): 167-180.

Pieczyńska, E. \& Ozimek, T. 1976. Ecological significance of lake macrophytes. International Journal of Ecology and Environmental Sciences 2: 115-128.

Radwan, S. \& Kornijów, R. 1998. Hydrobiologiczne cechy jezior-stan aktualny i kierunki zmian. Jeziora łęczyńskowłodawskie. In Monografia Przyrodnicza, edited by Harasimiuk M., Michalczyk, Z. \& Turczyński, M. Lublin: Biblioteka Monitoringu Środowiska. pp. 129-144.

Reedyk, S., Perpas, E. \& Chambers, P.A. 2001. Effect of single $\mathrm{Ca}(\mathrm{OH})_{2}$ doses on phosphorus concentration and macrophytes biomass of two boreal eutrophic lakes over 2 years. Freshwater Biology 46: 1075-1087.

Rooney, N. \& Kalff, J. 2000. Inter-annual variation in submerged macrophyte community biomass and distribution: The influence of temperature and lake morphometry. Aquatic Botany 68(4): 321-335.

Scheffer, M., De Redelijkheid, M. \& Noppert, F. 1992. Distribution and dynamics of submerged vegetation in a chain of shallow eutrophic lakes. Aquatic Botany 42: 199216.

Sculthorpe, C.D. 1967. The Biology of Aquatic Vascular Plants. London: Edward Arnold Publishers Ltd.

Sender, J. 2016. The effect of riparian forest shade on the structural characteristics of macrophytes in a mid-forest lake. Applied Ecology and Environmental Research 14(3): 249-261.

Sender, J. 2012. The dynamics of macrophytes in a lake in an agricultural landscape. Limnological Review 12(2): 93-100.

Sender, J. 2009. Analiza zmian sukcesyjnych zachodzących w fitocenozach wodnych I florze makrofitów badanych jezior w latach 1960-2009. In Ekologia krajobrazów hydrogenicznych Rezerwatu Biosfery Polesie Zachodnie, edited by Chmielewski, T.J. Lublin: University of Life Sciences in Lublin Press. pp. 161-190.

Sender, J. 2004. Struktura jakościowa I ilościowa zbiorowisk makrofitów w wybranych jeziorach Pojezierza Łęczyńsko - Włodawskiego. Doctoral dissertation, UAM. Poznań (Unpublished).

Sender, J. \& Grabowski, M. 2016. The relationship between land management and the nature of helophytes in small lakes (Eastern Poland). Limnological Review 16(1): 51-62.

Sender, J., Kolejko, M. \& Demetraki-Paleolog, A. 2015. Interactions within macrophytes in some small lakes from Polesie Lubelskie region. Teka Komisji Ochrony $i$ Ksztaltowania Środowiska Przyrodniczego 12: 102-110.

Shannon, C.E. \& Weaver, W. 1963. The Mathematical Theory of Communication. Urbana: The University of Illinois Press.

Spence, D.H.N. 1982. The zonation of plants in fresh water lakes. Advances in Ecological Research 12: 37-125.

Squires, M.M., Lesack, L.F.W. \& Huebert, D. 2002. The influence of water transparency on the distribution and abundance of macrophytes among lakes of the Mackenzie Delta, Western Canadian Arctic. Freshwater Biology 47(11): 2123-2135.

Szafer, W. \& Zarzycki, K. 1972. Szata Roślinna Polski. Warszawa: PWN.

Szajnowski, F. 1983. Biotic structure and processes in the lake system of river Jorka watershed (Masurian Lakeland, Poland). XI. Biomass and distribution of emergent macrophytes. Ekologia Polska 31(3): 793-800.

Tavechio, W.L.G. \& Thomaz, S.M. 2003. Effects of light on the growth and photosynthesis of Egeria najas Planchon Brazilian Archives of Biology and Technology 46(2): 203209.

Thiebaut, G., Guérold, F. \& Muller, S. 2002. Are trophic and diversity indices based on macrophyte communities pertinent tools to monitor water quality? Water Research 36(14): 3602-3610.

Tomaszewicz, H. 1987. Differentiation of the physical and chemical properties of bottom sediments in phytocenoses of Myriophylletum verticillati Soó 1927, Potamogetonetum natantis Soó 1927 and Hydrocharitetum morsus-ranae Langendock 1935 associations. Polskie Archiwum Hydrobiologii 34(2): 215-230.

Van Den Berg, M.S., Coops, H., Simons, J. \& De Keizer, A 1998. Competition between Chara aspera and Potamogeton pectinatus as a function of temperature and light. Aquatic Botany 60(3): 241-250.

Wang, H., Liu, J.L., Zhang, R., Liu, J., Zou, Y. \& Zhang, Z.M. 2017. Do aquatic macrophytes configuration mode impact water quality?. Sains Malaysiana 46(12): 2375-2381.

Weisner, S., Strand, J.A. \& Sandsten, H. 1997. Mechanisms regulating abundance of submerged vegetation in shallow eutrophic lakes. Oecologia 109: 592-599.

Xie, Y., An, S. \& Wu, B. 2005. Resource allocation in the submerged plant Vallisneria natans related to sediment type, rather than water-column nutrients. Freshwater Biology 50(3): 391-402.

Zdanowicz, A. 1994. Rola zlewni rolniczej i leśnej w transporcie biogenów (azotów i fosforów) do strumienia. Wiadomości Melioracyjne i Łąkarskie 37(2): 72-75.

Zieliński, P., Górniak, A. \& Choroszewska, K. 1999. Changes in water quality induced by the decomposition of plant detritus. Acta Hydrobiologica 41: 119-126.

Sender Joanna*

Department of Hydrobiology and Protection of Ecosystems

University of Life Sciences in Lublin

Dobrzańskiego 37

20-262 Lublin

Poland

Danuta Urban

Instytute of Soil Science and Environmental Engineering and Management

Department of Biological Bases of Forestry

University of Life Sciences in Lublin

Leszczyńskiego 7

20-069 Lublin

Poland 
Różańska-Boczula Monika

Department of Applied Mathematics and Computer Science

University of Life Sciences in Lublin

Poland, 28 Głęboka Street

20-950 Lublin

Poland
*Corresponding author; email: joanna.sender@up.lublin.pl

Received: 17 December 2018

Accepted: 7 February 2020 